\title{
Hepatotoxicity of pyrrolizidine alkaloids in rats in relation to human exposure
}

\author{
Hermann M. Bolt ${ }^{1}{ }^{\mathbb{D}}$
}

Received: 9 July 2020 / Accepted: 13 July 2020 / Published online: 16 July 2020

(c) The Author(s) 2020

Recently, Ebmeyer and colleagues published a 28-day feeding study with six pyrrolizidine alkaloids in rats (Ebmeyer et al. 2020). Pyrrolizidine alkaloids occur in honey, tea and herbal spices, which represent the main sources of human exposure (Bodi et al. 2014; EFSA 2017; Mulder et al. 2018). They consist of a common basic structure, the 1-hydroxymethylpyrrolizidine, esterified with one or two aliphatic monoor dicarboxylic acids (Stegelmeier et al. 1999; Wiedenfeld 2011). Uptake of high amounts of contaminated food may cause a human health risk (BfR 2018, 2019). Recently, it has been shown that single acute doses of senecionine to mice induced cytochrome P450-dependent destruction of sinusoidal endothelial cells (Hessel-Pras et al. 2020). However, relatively little is known about subchronic and chronic toxicity with doses relevant for human exposure. Therefore, Ebmeyer and colleagues used not acutely toxic doses of 0.1 to $3.3 \mathrm{mg} / \mathrm{kg}$ body weight for a 28 -day study in rats and performed genome-wide expression analyses of liver tissue. These doses are of human relevance, because consumption of contaminated tea may result in doses of $\sim 8 \mu \mathrm{g} / \mathrm{kg}$ in adults, while pyrrolizidine exposure of up to $3 \mathrm{mg} / \mathrm{kg}$ body weight was reported for infants, who consumed contaminated food. Liver enzymes were not increased in the exposed rats. However, at the highest tested doses, gene array analyses showed clear expression changes (Ebmeyer et al. 2020). A set of 36 commonly regulated genes was observed for the high-dose groups of four structurally different pyrrolizidine alkaloids. Among them, genes associated with DNA damage response and cell cycle regulation were enriched.

Hepatotoxicity represents a major focus in current toxicological research (Jansen et al. 2017; Ghallab et al. 2019a). Current studies with intravital imaging (Ghallab et al. 2019b;

Hermann M. Bolt

bolt@ifado.de

1 Leibniz Research Centre for Working Environment and Human Factors, Ardeystr. 67, 44139 Dortmund, Germany
Reif et al. 2017) and modeling (Vartak et al. 2016) give new insight into the complex interplay between the individual liver cell types during damage induction (Hoehme et al. 2010; Ghallab et al. 2016). Interspecies extrapolation remains a major challenge when toxicity studies are based on animal experiments (Thiel et al. 2015; Schenk et al. 2017); differences between the in vitro and in vivo situations represent not yet sufficiently solved challenges when human cell systems are used (Grinberg et al. 2014, 2018; Godoy et al. 2013, 2016).

Often risk evaluation is hampered by a lack of carefully performed subchronic or chronic animal studies with human relevant doses. Therefore, the present study of Ebmeyer et al. represents an important milestone in the current research on the hepatotoxicity of pyrrolizidine alkaloids.

Acknowledgments Open Access funding provided by Projekt DEAL.

\section{Compliance with ethical standards}

Conflict of interest The author declares that he has no conflict of interest.

Open Access This article is licensed under a Creative Commons Attribution 4.0 International License, which permits use, sharing, adaptation, distribution and reproduction in any medium or format, as long as you give appropriate credit to the original author(s) and the source, provide a link to the Creative Commons licence, and indicate if changes were made. The images or other third party material in this article are included in the article's Creative Commons licence, unless indicated otherwise in a credit line to the material. If material is not included in the article's Creative Commons licence and your intended use is not permitted by statutory regulation or exceeds the permitted use, you will need to obtain permission directly from the copyright holder. To view a copy of this licence, visit http://creativecommons.org/licenses/by/4.0/. 


\section{References}

BfR (2018) Aktualisierte risikobewertung zu gehalten an 1,2-ungesättigten pyrrolizidinalkaloiden (PA) in Lebensmitteln. BfR Opinion No 020(2018):1-13

BfR (2019) Pyrrolizidinalkaloidgehalt in getrockneten und tiefgefrorenen Gewürzen und Kräutern zu hoch Stellungnahme $\mathrm{Nr}$ 017/2019 des BfR vom 13 Mai 1-16

Bodi D, Ronczka S, Gottschalk C et al (2014) Determination of pyrrolizidine alkaloids in tea, herbal drugs and honey. Food Addit Contam Part A 31(11):1886-1895. https://doi.org/10.1080/19440 049.2014.964337

Ebmeyer J, Rasinger JD, Hengstler JG et al (2020) Hepatotoxic pyrrolizidine alkaloids induce DNA damage response in rat liver in a 28-day feeding study. Arch Toxicol 94(5):1739-1751. https:// doi.org/10.1007/s00204-020-02779-2

EFSA (2017) Risks for human health related to the presence of pyrrolizidine alkaloids in honey, tea, herbal infusions and food supplements-EFSA panel on contaminants in the food chain (CONTAM). EFSA J 15(7):4908. https://doi.org/10.2903/j. efsa.2017.4908

Ghallab A, Cellière G, Henkel SG et al (2016) Model-guided identification of a therapeutic strategy to reduce hyperammonemia in liver diseases. J Hepatol 64(4):860-871. https://doi.org/10.1016/j. jhep.2015.11.018

Ghallab A, Hofmann U, Sezgin S et al (2019a) Bile microinfarcts in cholestasis are initiated by rupture of the apical hepatocyte membrane and cause shunting of bile to sinusoidal blood. Hepatology 69(2):666-683. https://doi.org/10.1002/hep.30213

Ghallab A, Myllys M, Holland CH et al (2019b) Influence of liver fibrosis on lobular zonation. Cells 8(12):1556. https://doi.org/10.3390/ cells 8121556

Godoy P, Hewitt NJ, Albrecht U et al (2013) Recent advances in 2D and $3 \mathrm{D}$ in vitro systems using primary hepatocytes, alternative hepatocyte sources and non-parenchymal liver cells and their use in investigating mechanisms of hepatotoxicity, cell signaling and ADME. Arch Toxicol 87(8):1315-1530. https://doi.org/10.1007/ s00204-013-1078-5

Godoy P, Widera A, Schmidt-Heck W et al (2016) Gene network activity in cultivated primary hepatocytes is highly similar to diseased mammalian liver tissue. Arch Toxicol 90(10):2513-2529. https:// doi.org/10.1007/s00204-016-1761-4

Grinberg M, Stöber RM, Albrecht W et al (2018) Toxicogenomics directory of rat hepatotoxicants in vivo and in cultivated hepatocytes. Arch Toxicol 92(12):3517-3533. https://doi.org/10.1007/ s00204-018-2352-3
Grinberg M, Stöber RM, Edlund K et al (2014) Toxicogenomics directory of chemically exposed human hepatocytes. Arch Toxicol 88(12):2261-2287. https://doi.org/10.1007/s00204-014-1400-x

Hessel-Pras S, Braeuning A, Guenther G et al (2020) The pyrrolizidine alkaloid senecionine induces CYP-dependent destruction of sinusoidal endothelial cells and cholestasis in mice. Arch Toxicol 94(1):219-229. https://doi.org/10.1007/s00204-019-02582-8

Hoehme S, Brulport M, Bauer A et al (2010) Prediction and validation of cell alignment along microvessels as order principle to restore tissue architecture in liver regeneration. Proc Natl Acad Sci U S A 107(23):10371-10376. https://doi.org/10.1073/pnas.0909374107

Jansen PL, Ghallab A, Vartak N et al (2017) The ascending pathophysiology of cholestatic liver disease. Hepatology 65(2):722-738. https://doi.org/10.1002/hep.28965.Review

Mulder PPJ, López P, Castelari M et al (2018) Occurrence of pyrrolizidine alkaloids in animal- and plant-derived food: results of a survey across Europe. Food Addit Contam Part A 35(1):118-133. https://doi.org/10.1080/19440049.2017.1382726

Reif R, Ghallab A, Beattie L et al (2017) In vivo imaging of systemic transport and elimination of xenobiotics and endogenous molecules in mice. Arch Toxicol 91(3):1335-1352. https://doi. org/10.1007/s00204-016-1906-5

Schenk A, Ghallab A, Hofmann U et al (2017) Physiologically-based modelling in mice suggests an aggravated loss of clearance capacity after toxic liver damage. Sci Rep 7(1):6224. https://doi. org/10.1038/s41598-017-04574-z

Stegelmeier BL, Edgar JA, Colegate SM et al (1999) Pyrrolizidine alkaloid plants, metabolism and toxicity. J Nat Toxins 8(1):95-116

Thiel C, Schneckener S, Krauss M et al (2015) A systematic evaluation of the use of physiologically based pharmacokinetic modeling for cross-species extrapolation. J Pharm Sci 104(1):191-206. https:// doi.org/10.1002/jps. 24214

Vartak N, Damle-Vartak A, Richter B et al (2016) Cholestasis-induced adaptive remodeling of interlobular bile ducts. Hepatology 63(3):951-964. https://doi.org/10.1002/hep.28373

Wiedenfeld H (2011) Plants containing pyrrolizidine alkaloids: toxicity and problems. Food Addit Contam Part A 28(3):282-292. https:// doi.org/10.1080/19440049.2010.541288

Publisher's Note Springer Nature remains neutral with regard to jurisdictional claims in published maps and institutional affiliations. 